\title{
LEACHABILITY OF ARSENIC FROM WASTES OF ARSENIC REMOVAL UNITS USING MODIFIED TOXICITY CHARACTERISTIC LEACHING PROCEDURE
}

\author{
Md. Shafiqul Islam, Md. Abdullah Al Mamun ${ }^{1}$ Md. Nazmul Islam* \\ Department of Geology and Mining, University of Rajshahi, Rajshahi 6205, Bangladesh; \\ ${ }^{1}$ Department of Chemistry, University of Rajshahi, Rajshahi 6205, Bangladesh. \\ *Corresponding author (email: dr.m.nazmul.i@gmail.com)
}

\begin{abstract}
The present study evaluated the leaching of arsenic from sludge/waste of seven SONO filters that were operated in Rajarampur of Chapai Nawabganj district. For this, Toxicity Characteristic Leaching Procedure (TCLP) test was performed. To understand actual leaching of arsenic, a Simulated Natural Column (SNC) that is comparable to natural mature landfill was devised. Total arsenic concentration $\left(\mathrm{As}_{\mathrm{T}}\right)$ was measured by HG-AAS. The studied arsenic waste/sludge, having 7.0-9.2\% solid content, were alkaline in nature ( $\mathrm{pH}$ values of 7.9-8.7) and had arsenic and iron concentrations of 4.54-5.50 and 480-1039 mg kg${ }^{1}$ respectively. The TCLP test reveals that $6.4-19.4 \%$ (average 14\%) of arsenic was leached from the waste (average leachate $\mathrm{As}_{\mathrm{T}}$ before and after TCLP were 5.04 and $0.71 \mathrm{mg} \mathrm{kg}^{-1}$ respectively). After 102 days of continuous operation in $\mathrm{SNC} \mathrm{As}_{\mathrm{T}}$ in the leachate was found to be $0.223 \mathrm{mg} \mathrm{L}^{-1}$, although initial $\mathrm{As}_{\mathrm{T}}$ was $0.350 \mathrm{mg} \mathrm{L}^{-1}$. It was observed that $\mathrm{As}_{\mathrm{T}}$ in $\mathrm{SNC}_{\text {leachate increased }}$ up to 54 days (corresponding to $1.741 \mathrm{mg} \mathrm{L}^{-1}$ ) and then decreased in reciprocal quadratic pattern. Comparison shows that TCLP underpredicts $14.2 \%$ of arsenic leaching than that of SNC. Since leachate $\mathrm{As}_{\mathrm{T}}$ in both methods did not exceed the USEPA regulated level of $5 \mathrm{mg} \mathrm{L}^{-1}$, the studied waste/sludge was not hazardous.
\end{abstract}

Key words: Arsenic, leaching, TCLP, arsenic removal unit, arsenic waste/sludge, modified column.

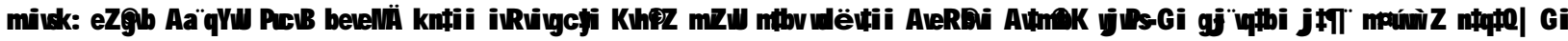

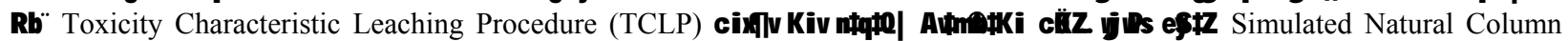

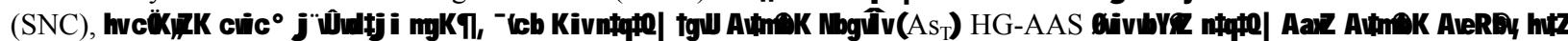

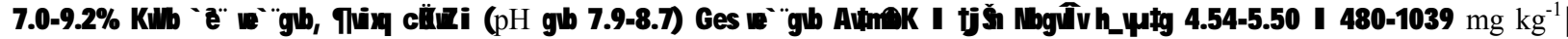

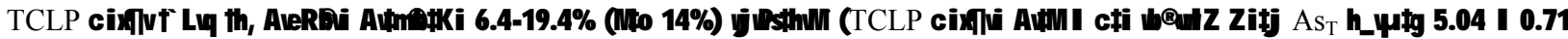

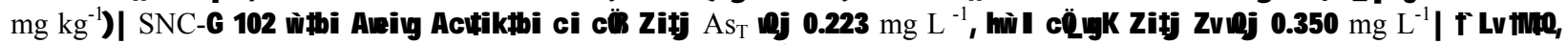

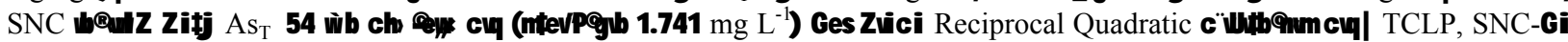

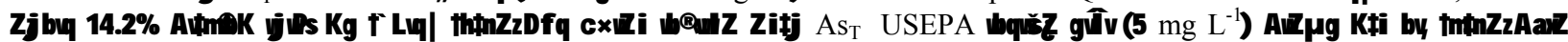

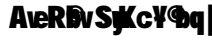

\section{Introduction}

Arsenic contamination in groundwater has become a health hazard for a large population of Bangladesh, West Bengal of India and other countries of the world such as Argentina, Chile, Taiwan, Japan and China (BGS 2001; WHO 2001). In Bangladesh, an estimated 24 million people are directly exposed to arsenic contamination and another 75 million are at risk (Engconsult Limited 2002). Nearly 7,600 patients have been identified and a few deaths related to arsenic diseases have also been reported (Engconsult Limited 2002; SOES-DCH 2000; Fazal et al. 2001). Evidently, Bangladesh is facing probably the largest mass poisoning in history.

To combat the arsenic problem, the Government of Bangladesh with the support of international agencies as well as local and international NGOs has launched a number of programs. This was done mainly by introducing different types of arsenic removal units (ARUs), e.g., Shapla, SONO (3-Pitcher) filter, ALCAN filter, Bucket Treatment Unit (BTU), SIDKO, etc., that work on the principle of chemical adsorption. The adsorbing materials involved include activated alumina, charcol, iron coated sand, iron coated brick chips and titanium (IV) oxide (Ali and Ahmed 2002). After repeating treatment of contaminated water, the adsorbing materials become saturated by continuously adsorbing arsenic and other materials. The used filter materials (arsenic sludge/waste) are then thrown out in a nearby ditch, latrine or open field without considering geological, hydrological, geochemical and environmental aspects that supports traditional arsenic waste disposal method in Bangladesh. This might adversely affect aquatic organisms such as bottom dwelling fishes, agricultural products, ecosystem and the environment of Bangladesh. This demands the sludge/waste to be tested for leaching of arsenic under natural conditions. 
The TCLP (Toxicity Characteristic Leaching Procedure) is designed to determine the mobility of both organic and inorganic analytes present in solid, liquid and multiphasic wastes. If one or more compounds of a waste exceed the US Environmental Protection Agency (USEPA) defined regulatory levels, the waste is considered to be hazardous (USEPA 1992). The TCLP test involves mixing the waste with acetic acid solution for 18 hours. The resulting TCLP extract is filtered, acid digested, and analyzed. If the TCLP extract has lower

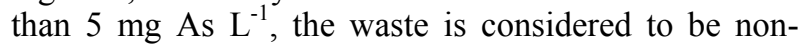
hazardous (EHSO 2007).

It is reported (USEPA 1996) that TCLP test underestimates leachate for some high alkaline wastes. This is due to low chelation activity of the TCLP acetate buffer or not considering redox reactions that occur in landfills. The State of California developed one alternative to the TCLP, named California WET (Waste Extraction Test) (Hooper et al 1998). To seek a suitable alternative, Ghosh et al in 2006 conducted detailed studies on leaching of arsenic from granular ferric hydroxide residuals under mature landfill conditions. In that work they simulated the biological and physicochemical conditions of a mature, mixed solid waste landfill. They operated a column and found that during the early stages of operation, most of the arsenic and iron were leached ( $80 \%$ and $65 \%$, respectively). Itle (2006) found that the percent solids and age of the residual could affect the test results. Eriksen (2002) investigated $15 \mathrm{NGO}$-led arsenic mitigation projects in 11 districts of Bangladesh and identified no hazardous leachate from the sludge produced from these units. Badruzzaman (2006) collected arsenic laden waste samples produced from Bucket Treatment Unit (BTU), buried in mud or mixed with organic matter for studying the anaerobic leaching of arsenic in a closed system. He suggested that a significant amount of arsenic was lost through bio-methylation.

After implementation of SONO filter no significant study has been carried out in Bangladesh to assess the leaching characteristics of the wastes produced. Since ARUs residuals might contain concentrated amounts of arsenic, the characterization and toxicity testing of the residuals are important. To understand the appropriate management of arsenic sludge/waste and to address the safety of human health led us to conduct this investigation.

Present work was carried out with two methodologies, namely (i) TCLP test and (ii) Leachability test considering mature landfill condition. These allowed us to evaluate actually whether a spent filter (arsenic sludge/waste) when dumped in traditional manner would create serious environmental problems in Bangladesh or not, both in short and in long term considerations.

\section{Materials and Methods}

Site selection: The study area is situated at the northwestern part of Bangladesh, namely, Rajarampur locality of Nawabganj Sadar thana of Chapai Nawabganj District. The study area is located roughly between $24^{\circ} 34^{\prime} \mathrm{N}$ to $24^{\circ} 35^{\prime} \mathrm{N}$ and $88^{\circ} 15^{\prime} \mathrm{E}$ to $88^{\circ} 18^{\prime} \mathrm{E}$ that covers an area of about 4.5 sq. kilometer (Fig. 1). The study area is accessible by concrete roads. Seven samples of arsenic sludge/waste were collected from the SONO filters (Fig. 2) that were being used by the affected people of the Rajarampur locality of Chapai Nawabganj district.

Materials: The chemicals used in this investigation were of high purity analytical grade. Distilled deionized water (DDW), obtained through the deionization plant (TYP-2500, Deng Yuan, China), was used throughout. Perkin Elmer pure atomic spectroscopy standard solution (Perkin Elmer, USA) of arsenic (CAS \# 7440-38-2) was used for calibration of arsenic. A number of standard solutions, reducing solutions, buffer solutions, ternary acid mixture and other solutions were prepared according to respective standard procedures (APHA 1995; Hesse 1994; Shimadzu). The other reagents were from Merck (Germany), Fluka (Switzerland) and Sigma Aldrich (USA). Two extraction fluids, used in the TCLP test, were prepared as follows:

Extraction fluid-1: It was prepared by dissolving $5.7 \mathrm{ml}$ of glacial acetic acid (Sigma Aldrich, USA) in 1L measuring flask containing $500 \mathrm{~mL}$ of DDW and 64.3 $\mathrm{ml}$ of $1 \mathrm{M}$ sodium hydroxide (Merck, Germany) solution was added and made up to the mark with DDW. The $\mathrm{pH}$ of the final fluid became 4.95 .

Extraction fluid-2: It was prepared by dissolving $5.7 \mathrm{ml}$ of glacial acetic acid (Sigma Aldrich, USA) in 1L measuring flask containing $500 \mathrm{~mL}$ of DDW and was made up to the mark with DDW to a volume of 1 liter. The $\mathrm{pH}$ of the final fluid was 2.9.

For the detection of total and fecal coliform LES MEndo Agar (Hi-Media, India) and Fecal Coliform M-FC Agar (Hi-Media, India) were used respectively. The 
cultural media were prepared according to the standard procedures (APHA 1995).

TCLP tests: First preliminary TCLP evaluations were performed with a minimum $100 \mathrm{~g}$ of semi-solid waste for: (1) Determination of percent solids, (2) Determination of whether the solid portion of the waste requires particle size reduction or not and (3) Determination of which of the extraction fluids are to be used for the TCLP test.

For determining percent solid in the arsenic sludge/waste, a $100 \mathrm{~g}$ of homogeneously mixed semisolid arsenic sludge/waste was transferred to the previously weighed cellulose filter paper $(0.8 \mu \mathrm{m}$ pore size) placed on the ceramic filter holder. After filtration with vacuum pump, the weight of the solid phase of the samples was determined by subtracting the weight of the liquid phase from the weight of the total waste sample. The percent solid was calculated as follows: Percent Solid $=($ Weight of solid $/$ Total weight of waste) $\times 100$. Since the particle size of the samples was smaller enough to pass through a $9.5 \mathrm{~mm}$ standard sieve, the particle size reduction of the wastes was not performed. To determine appropriate extraction fluid, $5.0 \mathrm{~g}$ of the solid phase (fresh weight) of the waste was transferred to a $500 \mathrm{~mL}$ beaker and $96.5 \mathrm{ml}$ of DDW was added to it. Then it was covered with a watch glass, stirred vigorously for 5 minutes using a magnetic stirrer followed by measuring $\mathrm{pH}$ of the samples. Since $\mathrm{pH}$ of all the samples were greater than 5.0, extraction fluid-2 were used for the TCLP test. The amount of extraction fluid-2 needed to add to the extraction vessel was determined as follows: Weight of extraction fluid $=(20$ $\times$ weight of waste filtered) $/ 100$.

The filtrate obtained from semi-solid sludge is defined as $1^{\text {st }}$ liquid phase. The solid materials obtained were then transferred to the extractor bottle of rotary agitation device and the appropriate amount extraction fluid-2 was added to the extractor vessel slowly. The extractor bottles were tightly closed (Teflon tape was used to ensure a tight seal) and rotated at $32 \mathrm{rpm}$ for $18 \pm 1$ hours at room temperature of $30^{\circ} \mathrm{C}$. To relieve the excess pressure due to formation of gases such as carbon dioxide and methylated arsenic, the extractor bottle were opened after definite interval (e.g., after 15, 30 and 60 minutes). The materials in the extractor vessel were separated in to its component liquid and solid phases by filtering through a cellulose filter. The filtrate obtained is defined as the TCLP extract ( $2^{\text {nd }}$ liquid phase). For further analyses, e.g., for determining total arsenic concentration $\left(\mathrm{As}_{\mathrm{T}}\right)$, the extracted liquid samples were acidified with $\mathrm{HNO}_{3}$ to keep $\mathrm{pH}<2$ and kept refrigerated at $4^{\circ} \mathrm{C}$. The individual phases were then analyzed separately for which the volume of the individual phases were determined. Final analyte concentration was determined using the following formula: Final analyte concentration $=\left[\mathrm{V}_{1} \mathrm{C}_{1}+\mathrm{V}_{2} \mathrm{C}_{2}\right] /\left(\mathrm{V}_{1}+\mathrm{V}_{2}\right)$ where, $V_{1}$ and $V_{2}$ are the volumes of $1^{\text {st }}$ and $2^{\text {nd }}$ phase liquids respectively, $\mathrm{C}_{1}$ and $\mathrm{C}_{2}$ are the concentrations $\left(\mathrm{mg} \mathrm{L}^{-1}\right)$ of $1^{\text {st }}$ and $2^{\text {nd }}$ phase liquids respectively.

\section{Leaching tests under Simulated Natural Column (SNC):}

The natural disposal conditions considered in the study include on land disposal in typical non-hazardous landfill dump or backyard and dumping in household ditch. Microbially active, mildly alkaline, anaerobic conditions characterize mature landfill (Christensen et al 2001). In the experimental section a PVC column, 30 inch in length and 6.3 inch in diameter, was operated in down flow mode (Fig. 3). A syringe delivered 0.35 $\mathrm{mL} / \mathrm{min}$ of influent, maintaining the water level at a total saturated bed volume of about $13 \mathrm{~L}$. The column was operated at room temperature of $30^{\circ} \mathrm{C} .5 \mathrm{~cm}$ thick pea gravel layers $(0.4-1.0 \mathrm{~cm}$ diameter) were provided above and below of the active bed ensuring even flow distribution. The active bed was composed of a mixture of $2.5 \mathrm{~L}$ arsenic sludge/waste, $3.0 \mathrm{~L}$ of anaerobic digester sludge, $5.9 \mathrm{~kg}$ of pond mud, $2.5 \mathrm{~kg}$ of Domar sand, $2.0 \mathrm{~kg}$ of brick chips, and $750 \mathrm{~g}$ of paper. Each component was lightly hand mixed before loading. Anaerobic digester sludge was collected from the Biogas plant of Bangladesh Agricultural Development Corporation (BADC), Rajshahi for natural organic matter. Pond mud was collected from the Jungle Genome Tank of the Institute of Biological Sciences, Rajshahi University, which was also organic matter enriched. Paper stripes of $90 \mathrm{~g}$ offset paper of about 2.5$3.0 \mathrm{~mm}$ wide were used. The papers were soaked in DDW and squeezed to pulp prior to mixing with the other components. Domar sand and brick chips were used for maintaining the porosity and even leaching. The effluent samples were collected from SNC after every three days interval. The samples were acidified to a $\mathrm{pH}<2$ to avoid precipitation and kept refrigerated.

Characterization of sludge, materials of SNC and feed water: The arsenic waste/sludge of SONO filters were characterized by measuring solid content, $\mathrm{pH}$, redox potential, concentrations of arsenic and iron. The materials of SNC and feed water were characterized by measuring $\mathrm{pH}$, redox potential, electrical conductivity, 
dissolved oxygen, total dissolved solids, concentrations of arsenic, iron, calcium and magnesium, total coliform and fecal coliform. All the parameters were measured using standard procedures and properly calibrated instruments.

Extraction and analysis for metal concentrations: Prior to analysis of water samples for total arsenic $\left(\mathrm{As}_{\mathrm{T}}\right)$ and total iron $\left(\mathrm{Fe}_{\mathrm{T}}\right)$ the aqueous samples were subjected to mild digestion with $\mathrm{HNO}_{3}$ (APHA 1995). But the water samples were not pretreated for estimation of calcium and magnesium. For estimation of $\mathrm{As}_{\mathrm{T}}, \mathrm{Fe}_{\mathrm{T}}, \mathrm{Ca}$ and $\mathrm{Mg}$ in soil samples, these were digested with $\mathrm{H}_{2} \mathrm{SO}_{4}-\mathrm{HClO}_{4}$ acid mixtures (Sakamoto et al 2001; Hesse 1994; Shimadzu). The digestates after dilution were analyzed for $\mathrm{As}_{\mathrm{T}}$ by Hydride Generation-Atomic Absorption Spectroscopy (HG-AAS) and for $\mathrm{Fe}_{\mathrm{T}}, \mathrm{Ca}$ and $\mathrm{Mg}$ by Flame-AAS using a Shimadzu-AA 6800 (Shimadzu Corporation, Kyoto, Japan) atomic absorption spectrophotometer. Prior to analysis by hydride generation, $1.5 \mathrm{~mL}$ of $37 \%(\mathrm{v} / \mathrm{v}) \mathrm{HCl}, 1.0 \mathrm{~mL}$ of $3 \%$ $(\mathrm{w} / \mathrm{v}) \mathrm{KI}$ (containing $3.0 \mathrm{~g} \mathrm{KI}$ and $5.0 \mathrm{~g} \mathrm{~L}(+)$-ascorbic acid in $100 \mathrm{~mL}$ water) and $5.0 \mathrm{~mL}$ of DDW were added to $10.0 \mathrm{~mL}$ of the digestates and allowed to stand for 30 minutes to reduce As(V) to As(III).

Microbiological examination: Membrane filter (MF) method was used to count total and fecal coliform bacteria. A volume of $100 \mathrm{ml}$ water was filtered through gridded nontoxic Nitrocellulose membrane filter (Millipore, USA), $47 \mathrm{~mm}$ in diameter having pore size of $0.45 \mu \mathrm{m}$, under manual vacuum condition. It was placed in a glass Petri dish, with support of absorbing pad, containing $4 \mathrm{ml}$ of the specific cultural media and incubated in a B-28 incubator (Binder, Germany) for 24 $\mathrm{h}$ at $35^{\circ} \mathrm{C}$ for total coliform and $44.5^{\circ} \mathrm{C}$ for fecal coliform. Finally the produced colonies were counted with the aid of a microscope.

Instrumentation: The atomic absorption spectrophotometer used in the investigation was Shimadzu-AA 6800 (Shimadzu Corporation, Kyoto, Japan) that can run with AA WizAArd software in both graphite furnace and flame mode. The system was equipped with an autosampler ASC-6100 (Shimadzu, Japan) and a hydride vapor generation system HVG-1 (Shimadzu, Japan). The HVG-1 comprises the peristalsistic pump that is used to send the sample, $5 \mathrm{M} \mathrm{HCl}$ and $0.4 \%$ $\mathrm{NaBH}_{4}$ solution to the reaction coil. The instrumental conditions used for $\mathrm{As}_{\mathrm{T}}$ determination by HG-AAS were the following: wavelength, $193.7 \mathrm{~nm}$; slit width, $1.0 \mathrm{~nm}$; lamp mode, BGC-D $\mathrm{D}_{2}$; lamp current, $12 \mathrm{~mA}$; flame type, Air- $\mathrm{C}_{2} \mathrm{H}_{2}$; fuel gas flow rate, $2.0 \mathrm{~L} \mathrm{~min}{ }^{-1}$; carrier gas, argon; reducing agent, $0.4 \%$ (w/v) $\mathrm{NaBH}_{4}$ in $0.5 \%(\mathrm{w} / \mathrm{v}) \mathrm{NaOH}$ solution, $\mathrm{NaBH}_{4}$ flow rate, $6 \mathrm{~mL}$ $\mathrm{min}^{-1}$; and cell temperature, $2200-2300^{\circ} \mathrm{C}$.

The rotary agitation apparatus (Fig. 4) used in the investigation was manufactured locally (STAR Engineering Works, Sayedpur) as per specification of the USEPA (USEPA 1992). It is capable of rotating the extraction bottle at $32 \mathrm{rpm}$ in end-over-end fashion. The basic features of the rotary agitation apparatus include steel frame, 3-phase 2HP motor, magnetic starter, steel shaft, bearing and four extraction bottles. The extraction bottles, 2.3 inch in internal diameter and 8.1 inch in length, were made of exclusively type 316-stainless steel (Japan) and were made vacuum and leak proof.

Statistical analyses: The datasets were treated separately for analyzing basic statistical parameters and making cross tabulations and cross plots. The statistical software used in the data analyses includes SPSS (release 13.0) statistical software package (SPSS Inc., Chicago, Illinois, 2004), STATGRAPHICS Centurion XV (release 12.2.14) software (StatPoint Technologies, Inc., Warrenton, Virginia, 2007). Mathematical models were established based upon simple and multiple regression analysis using SPSS, STATGRAPHICS Centurion XV and CurveExpert (release 1.34) and Microsoft Excel (release 12.0.4518.1014, 2006). The models were cross-checked by analyzing ANOVA, $P$ value, $r$ value (Pearson correlation coefficient) and Durbin-Watson statistics.

Quality control: All glasswares were treated with 10\% (v/v) $\mathrm{HNO}_{3}$ for $24 \mathrm{~h}$ and then rinsed three times with DDW followed by drying in an oven. Arsenic analysis was carried out following USEPA approved Quality Assurance/Quality Control (QA/QC) plan with a reagent blank, a duplicate and a spike for every 20 samples. The recoveries of arsenic from the environmental samples were $87.05-91.41 \%$. Moreover, after analyzing every 10 samples, readings of standard solutions were recorded to check the instrument.

\section{Results and Discussion}

Characterization of arsenic sludge/waste: The solid contents of all the samples of arsenic sludge/waste were found to be $7.0-9.2 \%$ (Table 1) with an average value of $8.3 \%$ reflecting that the waste/sludge were semi-solid with liquid portion predominated. The $\mathrm{pH}$ of the arsenic sludge/waste were 7.9-8.7 (average 8.3), indicating that they were alkaline in nature. This is attributed to the formation of $\mathrm{Fe}(\mathrm{OH})_{3}$. 
Table 1. Characterization of arsenic waste/sludge of SONO filters.

\begin{tabular}{cccccc}
\hline $\begin{array}{c}\text { Sample } \\
\text { ID }\end{array}$ & $\begin{array}{c}\text { Solid } \\
\text { Content } \\
(\%)\end{array}$ & pH & $\begin{array}{c}\text { Redox } \\
\text { Potential } \\
(\mathrm{mV})\end{array}$ & $\begin{array}{c}\text { Arsenic } \\
\text { conc. }(\mathrm{mg} \\
\left.\mathrm{kg}^{-1}\right)\end{array}$ & $\begin{array}{c}\text { Iron } \\
\text { conc. }(\mathrm{mg} \\
\left.\mathrm{kg}^{-1}\right)\end{array}$ \\
\hline SW* 01 $^{*}$ & 7.0 & 7.9 & 3.9 & 5.50 & 480 \\
SW 02 & 7.8 & 8.1 & 5.2 & 4.98 & 690 \\
SW 03 & 8.1 & 8.4 & 4.7 & 5.19 & 588 \\
SW 04 & 8.4 & 8.2 & 6.6 & 4.54 & 1008 \\
SW 05 & 8.9 & 8.4 & 8.2 & 5.17 & 693 \\
SW 06 & 9.0 & 8.7 & 11.3 & 5.00 & 957 \\
SW 07 & 9.2 & 8.3 & 4.1 & 4.90 & 1039 \\
Average & 8.3 & 8.3 & 6.3 & 5.04 & 779 \\
\hline
\end{tabular}

* SW stands for arsenic waste of SONO filter.
Table 2. Results of TCLP for total arsenic content.

\begin{tabular}{cccc}
\hline \multirow{2}{*}{$\begin{array}{c}\text { Sample } \\
\text { ID }\end{array}$} & \multicolumn{3}{c}{ Arsenic concentration $\left(\mathrm{mg} \mathrm{kg}^{-1}\right)$} \\
\cline { 2 - 4 } & $\begin{array}{c}\text { Before } \\
\text { TCLP }\end{array}$ & $\begin{array}{c}\text { After } \\
\text { TCLP }\end{array}$ & \% Released \\
\hline WS 01 & 5.50 & 0.96 & 17.45 \\
WS 02 & 4.98 & 0.32 & 6.40 \\
WS 03 & 5.19 & 0.65 & 12.52 \\
WS 04 & 4.54 & 0.37 & 8.15 \\
WS 05 & 5.17 & 0.81 & 15.67 \\
WS 06 & 5.00 & 0.92 & 18.40 \\
WS 07 & 4.90 & 0.95 & 19.38 \\
Average & 5.04 & 0.71 & 14.00 \\
\hline Fresents $\mathrm{mg} \mathrm{L}^{-1}$ & &
\end{tabular}

Table 3. Characterization of materials of simulated column and feed water.

\begin{tabular}{|c|c|c|c|c|}
\hline \multirow[t]{2}{*}{ Parameters } & \multirow[t]{2}{*}{ Units } & \multicolumn{2}{|c|}{ Materials of Simulated Column } & \multirow[t]{2}{*}{ Feed Water } \\
\hline & & Before Leaching Test & After Leaching Test & \\
\hline \multicolumn{5}{|l|}{ Physical } \\
\hline Temperature & ${ }^{0} \mathrm{C}$ & 31.1 & 26.9 & 28.0 \\
\hline $\mathrm{pH}$ & & 7.10 & 6.54 & 7.33 \\
\hline Redox Potential (Eh) & $\mathrm{mV}$ & 3.0 & 34.5 & 5.8 \\
\hline Dissolved Oxygen (DO) & $\mathrm{mg} \mathrm{L}^{-1}$ & 2.2 & 1.9 & 7.4 \\
\hline Electrical Conductivity (EC) & $\mu \mathrm{S} \mathrm{cm}^{-1}$ & 2300 & 160 & 766 \\
\hline Total Dissolved Solids(TDS) & $\mathrm{mg} \mathrm{L}^{-1}$ & 1472 & 103 & 491 \\
\hline \multicolumn{5}{|l|}{ Chemical } \\
\hline Total Fe concentration & $\mathrm{mg} \mathrm{L}^{-1}$ & 1200 & 135 & 3.95 \\
\hline Total As concentration & $\mathrm{mg} \mathrm{L}^{-1}$ & 7.5 & 2.0 & 0.006 \\
\hline Ca concentration & $\mathrm{mg} \mathrm{L}^{-1}$ & 70 & 29 & 126 \\
\hline Mg concentration & $\mathrm{mg} \mathrm{L}^{-1}$ & 36 & 24 & 87 \\
\hline Bicarbonate $\left(\mathrm{HCO}_{3}^{-}\right)$conc. & $\mathrm{mg} \mathrm{L}^{-1}$ & - & - & 369 \\
\hline \multicolumn{5}{|l|}{ Microbiological } \\
\hline Fecal Coliform & $\mathrm{CFU} / 100 \mathrm{~g}$ & $1.9 \times 10^{5}$ & $0.3 \times 10^{5}$ & 0 \\
\hline Total Coliform & $\mathrm{CFU} / 100 \mathrm{~g}$ & $70.0 \times 10^{5}$ & $5.4 \times 10^{5}$ & 0 \\
\hline
\end{tabular}

The total arsenic concentrations of the studied waste/sludge ranged $4.54-5.50 \mathrm{mg} \mathrm{kg}^{-1}$ on fresh weight basis (average $5.03 \mathrm{mg} \mathrm{kg}^{-1}$ ). The value is typical in the soil or sediment arsenic content in Bangladesh (BGS/DPHE, 2001). Total iron concentrations of the arsenic waste/sludge were abnormally high, 480-1039 $\mathrm{mg} \mathrm{kg}^{-1}$ (average $779 \mathrm{mg} \mathrm{kg}^{-1}$ ). The probable reasons for the high values include use of iron containing materials in SONO filter, high concentration of iron in feed water and formation of $\mathrm{Fe}(\mathrm{OH})_{3}$ flocks during treatment operation to which arsenic is adsorbed.

TCLP analysis: The concentrations of arsenic of the waste/sludge of the studied seven SONO Filters before and after TCLP test along with percent arsenic released are reported in Table 4.4. The data suggested that only $6.4-19.4 \%$ of arsenic was leached after performing TCLP. The arsenic concentration in TCLP extract was below $1.0 \mathrm{mg} \mathrm{kg}^{-1}$ in all cases (Fig. 4.3). 


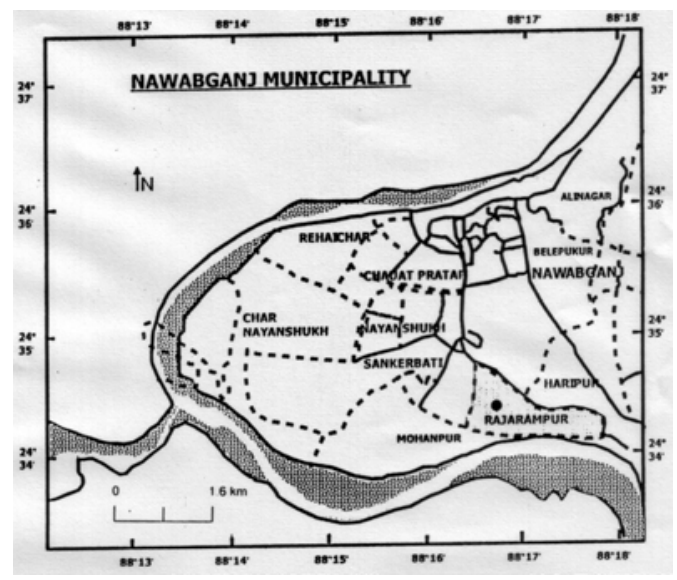

Fig. 1. Location map of the study area.

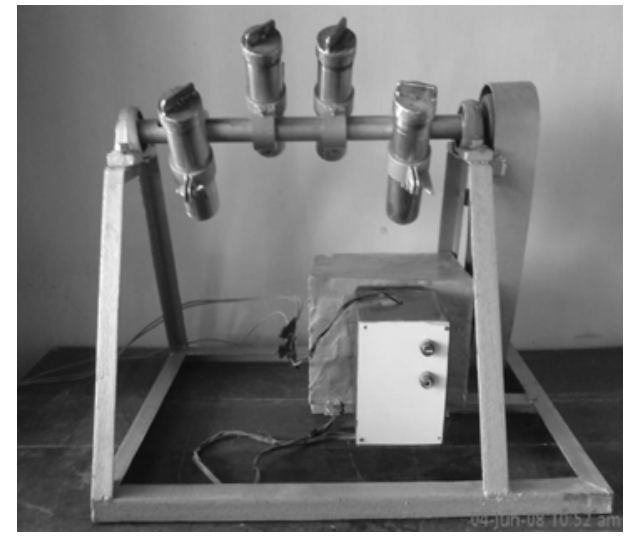

Fig. 4. Rotary agitation apparatus.

For arsenic (EPA Hazardous Waste Code D004), the regulatory level is $5.00 \mathrm{mg} \mathrm{kg}^{-1}$ (EHSO, 2007). As the arsenic concentration in the TCLP extract of the solid samples ranged between 0.32 and $0.96 \mathrm{mg} \mathrm{kg}^{-1}$, it is apparent that none of the studied arsenic sludge/waste would be toxic or hazardous in nature as per the standard of the USEPA. This means that the arsenic sludge/waste can be dumped into the soil without making any significant environmental pollution.

Characterization of materials of simulated column and feed water: When the waste was alkaline, an authentic procedure for leaching test that would provide accurate results under natural landfill conditions demanded. Since the arsenic sludge/waste of the SONO filters are alkaline in nature (average $\mathrm{pH}$ value of 8.3 ), we introduced a simulated column in which anaerobic digester sludge, pond mud, paper, sand and brick chips were introduced in a ratio that was similar to natural landfill conditions. The physical, chemical and microbiological properties of the simulated column materials as well as feed water are presented in Table 3 .

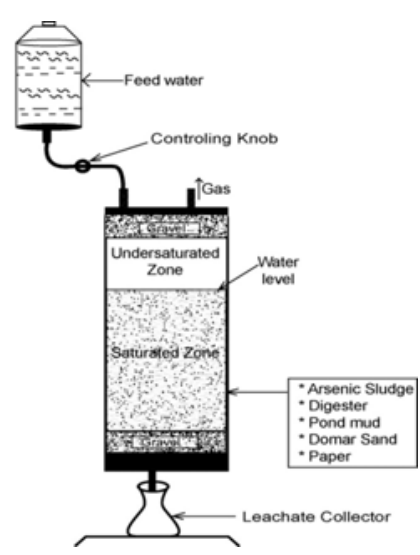

Fig. 3. Schematic diagram of simulated natural column (SNC).

Fig. 2. A SONO filter.

Obviously, the simulated column materials were neither acidic nor alkaline. The low values of redox potential and dissolved oxygen indicated that the materials were in reducing environment. The high values of electrical conductivity and total dissolved solids indicated that many potential ions were present in the column materials. The total concentration of arsenic, calcium and magnesium were characteristics of wet land or dumped land of Bangladesh (BGS 2001). But very high value of total iron concentration was observed. The coliform bacteria of order of $10^{5}$ per $100 \mathrm{~g}$ of soil indicates microbial activity in the column materials. These facts reflected that the simulated column materials were very close to mature natural landfills.

The feed water was almost neutral $(\mathrm{pH} 7.33)$. The high bicarbonate concentration and relatively high concentrations of calcium, magnesium and iron indicated that the water was hard. Hence, high values of electrical conductivity and total dissolved solids were observed. The feed water also contained dissolved oxygen to considerable extent. The total arsenic concentration in the feed water was very low $(0.006 \mathrm{mg}$ $\mathrm{L}^{-1}$ ), which is below the WHO guideline value for drinking water $\left(0.010 \mathrm{mg} \mathrm{L}^{-1}\right)$. The water did not contain any fecal bacteria to perform microbial activity.

Leaching from simulated column: The leachates obtained from the mature simulated column were collected after every third day interval up to 102 days. The collected samples were acidified, digested with nitric acid and analyzed for total arsenic and iron concentrations. Regression analysis for $\mathrm{As}_{\mathrm{T}}$ showed that the fitted model was Reciprocal Quadratic, $y=1 /(a+b x$ $\left.+\mathrm{cx}^{2}\right)$, where $\mathrm{y}$ is total As concentration of leachate in $\mathrm{mg} \mathrm{L}^{-1}$ and $\mathrm{x}$ time in days (Pearson correlation coefficient, $r=0.947$; Fig. 5 a). 

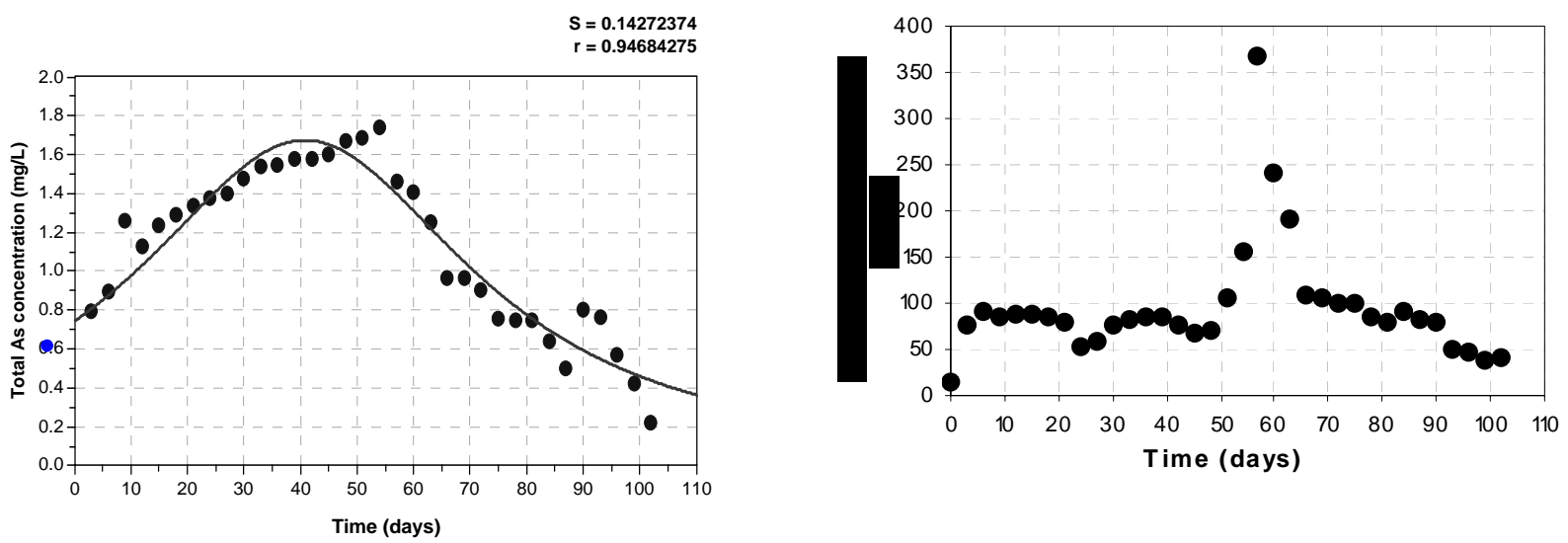

Fig. 5. Leachable arsenic (left) and iron (right) from simulated natural column (SNC).
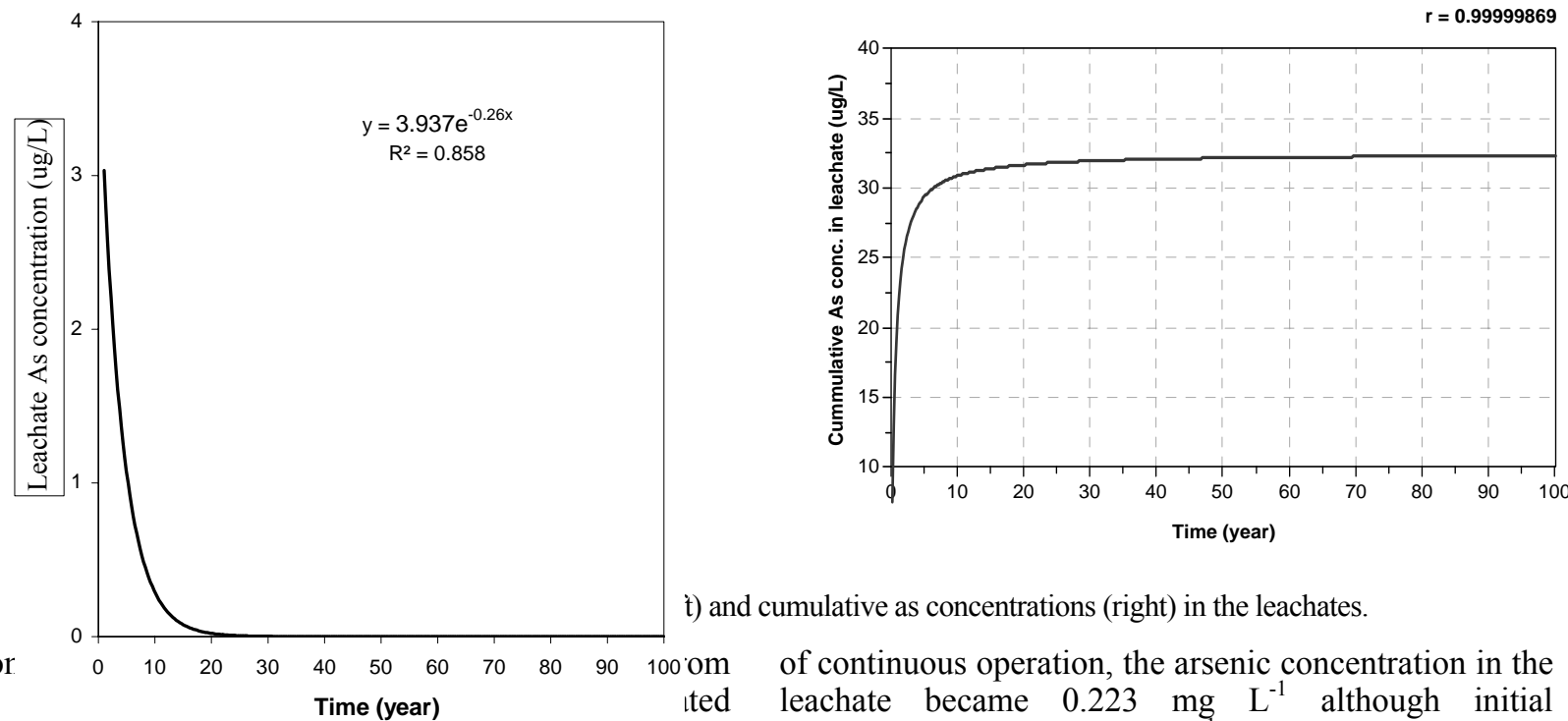

t) and cumulative as concentrations (right) in the leachates.

Fror

the Time (year)
100 om ited

column was tirst graqually raised reacned to the maximum (corresponding to the arsenic concentration of $1.741 \mathrm{mg} \mathrm{L}^{-1}$ at $54^{\text {th }}$ day of experiment) and then fell exponentially. The increase in arsenic concentration can be illustrated by the fact that the microbial reduction using dissolved organics from anaerobic digester sludge became very active producing less sorbed As(III) (BGS 2001). After reaching the peak value, the decreasing trend might be explained by the microbial methylation of arsenic to produced volatile compounds of arsenic (Bhumbla and Keefer 1994). This is in agreement with many authors (Shariatpanahi et al 1982; Challenger et al 1933) that reported that several fungi (e.g., Penicillum brevicaulis and Candiada fumicola) and bacteria (e.g., Nocardia sp. and Aeromonas sp.) had been found to methylate inorganic arsenic by an initially reducing arsenate fraction to arsenite followed by methylation and released to the environment. Although noticeable fluctuation was observed, but the ultimate trend was decreasing. Because after 102 days of continuous operation, the arsenic concentration in the leachate became $0.223 \mathrm{mg} \mathrm{L}^{-1}$ although initial concentration was $0.350 \mathrm{mg} \mathrm{L}^{-1}$ and averagely increased for first 40 days and decreased for the rest 62 days.

From Figure 5. b it follows that iron leaching shows a rough fluctuation at different interval of the experiment. Generally, the iron leaching was gradually increased from the beginning to 57 days of the experiment probably due to increase in microbial reduction and enhanced iron leaching (conversion of $\mathrm{Fe}^{3+}$ to $\mathrm{Fe}^{2+}$ ). The iron leaching was declined with high amount afterwards. The continuous decrease in iron concentration at the end period of the experiment may be a consequence of declining microbial activity.

It was noticed that at any instant the higher arsenic concentration was generally associated with higher iron concentration. This situation might be for the active iron dissolution and recrystallization (Fredrickson et al 1998). As a result, newly precipitated iron phases (magnetite or goethite) had a lower arsenic sorption 
capacity than the original arsenic sludge. Moreover, at the end of the experimental period almost major portion of the iron had leached out.

Prediction of leaching with respect to time: Based upon the lechate data, the leachable arsenic concentrations from simulated natural column for different intervals were plotted, the best-fitted model was determined and the extrapolation was made. The determined values were further plotted for leachate arsenic concentration versus time. The fitted model found was exponential, y $=a \cdot e^{b x}$ (where $y$ was leachate As concentration in $\mu \mathrm{g} \mathrm{L}^{-1}$ and $x$ time in year) with $r=0.927$ (Fig. 6.a)). This figure gives 100 year projected arsenic concentrations in the leachates. Obviously, the leachate arsenic concentration decreases exponentially with time. For example, after 13 years the estimated arsenic content in the leachate would be less than $0.10 \mu \mathrm{g} \mathrm{L}^{-1}$, although it would be $20.92 \mu \mathrm{g} \mathrm{L}^{-1}$ at first year.

The cumulative arsenic concentrations in the leachates were also plotted against time. The regression equations of the fitted model were found in Morgan-Mercer-Florin (MMF) form, $y=\left(a b+c x^{d}\right) /\left(b+x^{d}\right)$, with $r=0.999$ (Fig. 6.b)). It is obvious that most of the arsenic is leached within first 10 years. After 50 years, there will virtually no change in cumulative arsenic concentration in the leachates.

\section{References}

Ali MA, Ahmed MF. 2002. Environmental Chemistry of Arsenic. Papers presented on 'Arsenic Contamination in Bangladesh' at International Training Network (ITN) Center, Dhaka, Bangladesh. May 18-23, 2002.

APHA. 1995. Standard methods for the examination of water and wastewater. $19^{\text {th }}$ Edition. United Book Press, Inc., Baltimore, Maryland. American Public Health Association.

Badruzzaman ABM. 2006. Leaching of arsenic wastes of arsenic removal systems. Bangladesh University of Engineering and Technology (BUET), Dhaka, Bangladesh.

BGS. 2001. Arsenic contamination of groundwater in Bangladesh. In: BGS Technical Report WC/00/19, Ed., DG Kinniburgh, PL Smedley, vol. 2, pp. 77-207. British Geological Survey, Keyworth, UK.

Bhumbla DK, Keefer RF. 1994. Arsenic mobilization and bioavailability in soils. In: Arsenic in the Environment, Ed. JO Nriagu, Part I, John Wiley \& Sons, New York, pp. 52-82.

Challenger F, Higginbottom C, Ellis L. 1933. The formation of organo-metalloidal compounds by micro-organisms. Part I, Trimethylarsine and dimethylarsine, J. Chem. Soc., 95-101. Available: www.rsc.org/ebooks/2008/ BK9780854041367/ BK9780854041367-00190.pdf [accessed May 25 2011]

EHSO. 2007. Toxicity Characteristic Leaching Procedure (TCLP). Environmental Health \& Safety Online. Available: http://www.ehso.com [accessed September 25 2007]
Engconsult Limited. 2002. Arsenic calamity of Bangladesh. In: Statistics of arsenic calamity. Engconsult Limited, Toronto, Canada. Available: http://www.eng-consult.com/arsenic/ arsstat.html [accessed 22 June 2009].

Eriksen N. 2002. A study of arsenic treatment technologies and leaching characteristic of arsenic contaminated sludge. Bangladesh Consultants Ltd., Dhaka, Bangladesh.

Fazal MA, Kawachi T, 2001. Ichion E. Extent and severity of groundwater arsenic contamination in Bangladesh. Water International 26(3), 370-379.

Fredrickson JK, Zachara JM, Kennedy DW, Dong H, Onstott TC, Hinman NW, Li SM. 1998. Biogenic iron mineralization accompanying the dissimilatory reduction of hydrous ferric oxide by a groundwater bacterium. Geochimica et Cosmochimica Acta 62, 3239-3257.

Ghosh A, Mukiibi M, Saez AE, Ela WP. 2006. Leaching of Arsenic from granular ferric hydroxide residuals under mature landfill conditions. Environ. Sci. Technol. 40, 6070-6075.

Hesse PR. 1994. A textbook of soil chemical analysis. CBS Publishers and Distributor, Delhi, India.

Hooper K, Iskander M, Sivia G, Hussein F. Hsu J, Deguzaman M, Odion Z, Ilejay Z, Sy F, Petreas M, Simmons B. 1998. Toxicity characteristic leachate procedure fails to extract oxoanion-forming elements that are extracted by municipal solid waste leachates. Environ. Sci. Technol. 32, 3825-3830.

Itle CH. 2001. Properties of waste resulting from arsenic removal processes in drinking water treatment. Virginia Polytechnic Institute and State University, Blaksburg VA.

Sakamoto H, Susa Y, Ishiyama H, Tomiyasu T, Anazawa K. 2001. Determination of trace amounts of total arsenic in environmental samples by hydride generation flow injection-AAS using a mixed acid as a pretreatment agent. Analytical Sciences 17, 1067-1071.

Shariatpanahi M, Anderson AC, Abdelghani AA. 1982. Uptake and distribution of sodium arsenate by bacterial cells. Trace Subst. Environ. Health 16, 170-173.

Shimadzu. Atomic Absorption Spectrophotometry Cookbook. Shimadzu Corporation, Kyoto, Japan.

SOES-DCH. 2000. Groundwater arsenic contamination in Bangladesh. A. summary of 239 days field survey from August 1995 to February 2000, B. Twenty-seven days detailed field survey information from April 1999 to February 2000. School of Environmental Studies, Jadavpur University, Calcutta, India and Dhaka Community Hospital, Dhaka, Bangladesh. Available: http://www.eng-consult.com/arsenic/article/

BANGLAREPORT.pdf [accessed 22 June 2009].

USEPA. 1992. Toxicity Characteristic Leaching Procedure, Test Method 1311. U.S. Environmental Protection Agency, Washington, DC.

USEPA. 1996. Hazardous Waste Characteristic Scoping Study. Office of Solid Waste and Emergency Response, U.S. Environmental Protection Agency, Washington, DC. Federal Registrar 3-42-3-47.

WHO. 2001. Arsenic in Drinking Water. World Health Organization, Geneva. Fact Sheet No. 210.

Manuscript received on 4 June 2011 and revised on 13 October 2011 